Vol. 2 No. 2 Juli 2020

\title{
SURVEI PENDAHULUAN PENTINGNYA AHLI YANG DITUNJUK OLEH PENGADILAN DALAM PEMBUKTIAN PERKARA PERDATA LINGKUNGAN HIDUP
}

\section{Preliminary Survey on the Importance of Court-Appointed Experts in the Proof of Civil Environment Cases}

\author{
Cecep Aminudin*, Efa Laela Fakhriah, Ida Nurlinda, Isis Ikhwansyah \\ Fakultas Hukum, Universitas Padjadjaran \\ *cecepaminudin@gmail.com \\ Naskah dikirim : 5 April 2020 \\ Naskah diterima untuk diterbitkan : 7 Juni 2020
}

\begin{abstract}
The role of experts is often needed in the resolution of civil environmental disputes in the court. However, access to experts is considered as one of the obstacles. This study aims to understand the views of experts on scientific assistance in the process of legal decisions making in civil environmental cases in court linked to the procedural law. The research is an empirical legal research in the form of a survey where respondents are determined purposively and the data are analyzed quantitatively and qualitatively. Based on the results of the survey, not all experts who are capable to be an expert according to their fields of expertise are willing to become experts in civil environmental cases on the grounds that they are not comfortable with the court atmosphere, worried that they cannot provide objective information, do not want to be involved in a conflict, not yet familiar and or due to time constraints. However, not a few are willing to become experts according to their field of expertise in civil environmental cases in court on the grounds as a form of duty and community service, assisting the court in making good decisions and assisting the parties to the dispute who ask for help in dispute resolution. Scientific assistance in the form of expert statements is more preferred to be sought so that those asking for help are the court or judges including with the agreement of the parties to the dispute so that the expert can be more objective and neutral in providing opinions according to their expertise. Experts appointed by the court may also be able to overcome the constraints of unequal access to experts among the parties. Even so, it does not rule out the possibility of the parties to the dispute to ask for expert help in accordance with the needs of environmental case conditions.
\end{abstract}

Keywords: experts, court-appointed, civil, environment

\begin{abstract}
Abstrak
Peranan ahli seringkali dibutuhkan dalam penyelesaian sengketa perdata lingkungan hidup di pengadilan. Namun akses terhadap ahli dianggap sebagai salah satu kendala. Penelitian ini bertujuan untuk lebih memahami pandangan ahli terhadap bantuan ilmu pengetahuan dalam proses pengambilan keputusan hukum dalam perkara perdata lingkungan hidup di pengadilan dikaitkan dengan hukum acara di pengadilan. Penelitian merupakan penelitian hukum empiris dalam bentuk survei di mana responden ditentukan secara purposif dan data dianalisis secara kuantitatif maupun kualitatif. Berdasarkan hasil penelitian diketahui tidak semua ahli yang layak menjadi ahli sesuai bidang keahliannya bersedia untuk menjadi ahli dalam perkara perdata lingkungan hidup di pengadilan dengan alasan karena kurang nyaman dengan suasana pengadilan, khawatir tidak dapat memberikan keterangan yang objektif, tidak ingin terlibat dalam konflik, belum tahu caranya atau belum pernah serta kendala waktu. Namun demikian, tidak sedikit yang bersedia untuk menjadi
\end{abstract}


Vol. 2 No. 2 Juli 2020

ahli sesuai bidang keahliannya dalam perkara perdata lingkungan hidup di pengadilan dengan alasan sebagai bentuk tugas dan pengabdian pada masyarakat, membantu pengadilan agar dapat membuat keputusan yang baik serta membantu para pihak yang bersengketa yang meminta bantuan dalam penyelesaian sengketa di pengadilan. Bantuan ilmu pengetahuan dalam bentuk keterangan ahli lebih cenderung diminati agar yang meminta bantuan adalah pengadilan atau hakim termasuk dengan kesepakatan para pihak yang bersengketa agar ahli lebih dapat bersikap objektif dan netral dalam memberikan pendapat sesuai keahliannya. Ahli yang ditunjuk pengadilan juga mungkin bisa mengatasi kendala ketidakseimbangan akses terhadap ahli diantara para pihak. Meskipun demikian, hal tersebut tidak menutup kemungkinan para pihak yang bersengketa untuk meminta bantuan ahli sesuai dengan kebutuhan kondisi kasus lingkungan hidup.

Kata Kunci: ahli, ditunjuk pengadilan, perdata, lingkungan hidup

\section{PENDAHULUAN}

\subsection{Latar Belakang}

Menurut arti dalam Kamus Besar Bahasa Indonesia (KBBI) ahli bentuk tidak baku akhli memiliki empat arti. Yaitu sebagai kata benda (noun) berarti orang yang mahir, menguasai, paham sekali dalam suatu ilmu atau orang yang memiliki kemampuan dalam menelaah, menganalisis, menginterpretasi suatu ilmu. Sebagai kata kerja (adverb) ahli memiliki arti mahir benar, sangat mendalam dalam suatu ilmu. Sebagai kata kerja ahli juga memiliki arti sangat tekun dan gemar melaksanakan suatu kewajiban. Sebagai kata benda, ahli juga berarti pangkat dalam jabatan atau tugas fungsional, misalnya peneliti (Pusat Bahasa Departemen Pendidikan Nasional 2015). Ahli dalam Bahasa Inggris disebut juga expert atau specialist, skilled highly competent, atau professional (Echols dan Shadily 1992). Dalam Kamus Merriam Webster expert sebagai kata benda noun berarti one with the special skill or knowledge representing mastery of a particular subject. Sebagai kata sifat (adjective) expert berarti having, involving, or displaying special skill or knowledge derived from training or experience (Mish 2004).

Dalam hukum acara perdata ahli adalah orang yang memiliki pengetahuan khusus di bidang tertentu. Seseorang dikatakan sebagai ahli apabila memiliki pengetahuan khusus (spesialis) di bidang ilmu pengetahuan tertentu sehingga benar-benar kompeten di bidang tersebut, keahlian tersebut dapat dalam bentuk keterampilan (skill) karena hasil latihan atau pengalaman, sedemikian rupa sehingga spesialisasi yang dimilikinya sehingga 
Vol. 2 No. 2 Juli 2020

keterangan dan penjelasan yang diberikannya dapat membantu menemukan fakta melebihi kemampuan pengetahuan umum orang biasa (Fakhriah 2017).

Dalam konteks pengambilan keputusan hukum dalam perkara perdata di pengadilan dalam Pasal 154 (1) Reglemen Indonesia yang diperbarui (Het Herziene Indonesisch Reglement) disebutkan "jika pengadilan negeri menganggap perkara itu dapat menjadi lebih terang kalau diperiksa atau dilihat oleh ahli, maka ia dapat mengangkat ahli itu, baik atas permintaan kedua pihak, maupun karena jabatannya. Dalam hal demikian, akan ditentukan hari persidangan, supaya pada hari itu ahli itu memberi laporan, baik dengan surat maupun dengan lisan, dan meneguhkan laporan itu dengan sumpah (Pasal 154 (2)). Orang yang tak boleh didengar sebagai saksi tidak boleh diangkat jadi ahli (Pasal 154 (3)). Pengadilan negeri sama sekali tidak wajib menuruti pendapat ahli itu, jika pendapat itu berlawanan dengan keyakinannya ((Pasal 154 (4))). Pada seseorang, tidak. dapat dituntut untuk mengetahui segala-galanya. Demikian pula pada seorang hakim, oleh karena itu hakim diberi kesempatan apabila dipandang berfaedah, kemungkinan untuk minta pertolongan atau pendapat seorang ahli. Pada hakekatnya hal tersebut adalah merupakan alat atau sarana bagi hakim untuk mencari kebenaran yang hakiki agar dapat menjatuhkan keputusan yang adil (Fakhriah 2015).

Meskipun penyelesaian sengketa lingkungan dapat dilakukan di luar pengadilan namun terkadang hal tersebut tidak menyelesaikan masalah secara tuntas (Fakhriah 2013). Sehingga penyelesaian secara litigasi di pengadilan tetap dilakukan. Peranan ahli, meskipun seringkali dibutuhkan dalam pembuktian perkara perdata lingkungan hidup di pengadilan (Takdir Rahmadi 2012; Paulus Effendi Lotulung 1993), namun akses terhadap ahli dianggap sebagai salah satu kendala. Hal tersebut terutama bagi para pihak yang bersengketa yang secara sosial ekonomi lemah dan lembaga swadaya masyarakat (LSM) atau organisasi lingkungan yang memiliki hak gugat di pengadilan (Nicholson 2009; Mas Achmad Santosa dkk. 1997). Saksi ahli dipergunakan di pengadilan terkait spesialisasinya dalam suatu disiplin ilmu sehingga mampu memberikan interpretasi atau komentar ilmiah (scientific verification) yang dipercaya diantaranya atas hasil analisis yang dilakukan oleh laboratorium (Sholihah 2011). 
Vol. 2 No. 2 Juli 2020

\subsection{Tujuan Penelitian}

Penelitian ini bertujuan untuk memahami bagaimana pandangan ahli terhadap bantuan ilmu pengetahuan dalam bentuk keterangan ahli dalam proses pengambilan keputusan hukum dalam penyelesaian sengketa perdata lingkungan hidup di pengadilan dikaitkan dengan hukum acara perdata.

\section{STUDI PUSTAKA}

Pemahaman ahli terhadap konteks pengambilan keputusan hukum di pengadilan serta bagaimana pengadilan memahami kebutuhan ahli itu sendiri merupakan hal yang penting bagi efektifnya bantuan ilmu pengetahuan dalam pengambilan keputusan hukum di pengadilan. Mereview buku karya Tal Golan yang berjudul Laws of Men and Laws of Nature: The History of Scientific Expert Testimony in England and America yang diterbitkan Harvard University Press tahun 2004, Sheila Jassanof mengungkapkan, saling pemahaman antara ahli dengan pengadilan diperlukan agar proses transfer pengetahuan dapat berjalan lancar. Hakim perlu memahami informasi dan pengetahuan yang disampaikan ahli dan berfikir sebagaimana layaknya seorang ilmuwan. Sistem pengambilan keputusan hukum yang menempatkan ahli sebagai pihak yang netral dan mampu memberikan keterangan yang obyektif dianggap lebih diutamakan dibandingkan sistem yang menempatkan ahli seperti sebuah perusahaan yang tergantung pada pihak yang membutuhkan bantuan (Jasanoff 2005). Hal tersebut juga dipandang peneliti relevan dalam penyelesaian sengketa perdata lingkungan hidup di pengadilan.

Menurut Ozawa, dalam proses pengambilan keputusan dalam penyelesaian sengketa lingkungan, akses terhadap keahlian ilmiah seharusnya bersifat terbuka untuk semua pihak yang berkepentingan, terbebas dari kepentingan politik dan bertujuan untuk mengedukasi para pihak yang bersengketa dengan informasi ilmiah yang disajikannya (Ozawa 1996).

Menurut Pedoman Penanganan Perkara Lingkungan Hidup, untuk menentukan adanya pencemaran dan/atau kerusakan lingkungan, hakim dapat menunjuk ahli independen dengan biaya berdasarkan kesepakatan kedua belah pihak. Terkait dengan pembuktian ilmiah, apabila ada dua keterangan ahli yang berbeda maka hakim dapat: 1) memilih 
Vol. 2 No. 2 Juli 2020

keterangan berdasarkan keyakinan hakim dengan memberikan alasan dipilihnya keterangan alat bukti yang dihadirkan oleh keterangan ahli; atau 2) menghadirkan ahli lain dengan pembebanan biaya berdasarkan kesepakatan para pihak; 3) menerapkan prinsip kehati-hatian. Kriteria ahli yang dapat diajukan sebagai ahli perkara perdata, pidana dan tata usaha negara lingkungan hidup adalah sebagai berikut: a. Memiliki disiplin ilmu sesuai dengan perkara yang dibuktikan melalui ijazah, minimal S2 (akademis); atau mendapat pengakuan masyarakat sebagai ahli; b. Pernah menyusun atau membuat karya ilmiah atau penelitian relevan (pakar); c. Aktif dalam seminar atau lokakarya dan tercantum daftar riwayat hidup (CV). Penunjukkan ahli oleh hakim dalam hal terjadi perbedaan keterangan ahli dan hakim belum yakin atau dalam hal tergugat dan penggugat tidak mengajukan ahli, hakim dapat menunjuk ahli lain yang dianggap netral atau dapat menerapkan precautionary principles. Dalam hal hakim menunjuk ahli lain, maka hakim dapat menetapkan pihak yang harus menanggung biaya ahli (Mahkamah Agung 2013).

Menurut Windu Kisworo, secara umum pengaturan hukum di Indonesia sudah memuat prinsip-prinsip dari kriteria Daubert yang mensyaratkan agar teori dan metode yang digunakan dalam menentukan bukti ilmiah telah teruji secara ilmiah (falsifiability test), potential error rate-nya rendah serta telah melalui peer review dan telah diterima oleh komunitas ilmiah (general acceptance). Selain itu prinsip-prinsip tersebut juga telah secara umum digunakan dalam penanganan perkara perdata lingkungan. Namun demikian, hal ini belum dapat dianggap cukup. Terdapat beberapa tantangan yang dihadapi di lapangan yaitu bahwa aturan yang ada selama ini belum memberikan panduan yang lengkap untuk menilai validitas bukti ilmiah yang diajukan dalam persidangan dan pengetahuan khusus yang dimiliki oleh ahli. Untuk itu, peraturan dan pedoman tentang pembuktian dalam perkara lingkungan di pengadilan perlu disempurnakan. Perhatian khusus perlu diberikan pada aspek penggunaan metode ilmiah dalam menentukan validitas bukti ilmiah, serta pendapat ahli yang harus didasarkan oleh pengetahuan khusus. Aspek-aspek lain yang relevan dan penting perlu diidentifikasi lebih lanjut secara komprehensif. Namun demikian, perlu diakui bahwa penyempurnaan peraturan yang diusulkan tersebut akan memberikan tantangan tersendiri bagi hakim (Kisworo 2018).

106

Fakultas Hukum Universitas Komputer Indonesia| http://ojs.unikom.ac.id/index.php/law

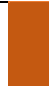


Vol. 2 No. 2 Juli 2020

Pengaturan yang detail berarti mensyaratkan hakim untuk memiliki pengetahuan ilmiah (scientific knowledge) yang memadai. Tentunya hakim tidak diharapkan untuk dapat memiliki pemahaman layaknya seorang ilmuwan. Namun, hakim diharapkan mampu merumuskan pertanyaan-pertanyaan penting dalam menilai validitas bukti ilmiah dan kualifikasi saksi ahli, agar dapat memberikan pendapat ilmiah yang relevan dengan perkara. Oleh sebab itu, penguatan hukum tersebut juga perlu didukung dengan adanya pelatihan khusus bagi hakim, dengan materi dan metode yang tepat. Metode yang dipakai harus dapat membantu hakim dalam memilah dan memilih bukti ilmiah yang relevan, dan menerapkan ke dalam suatu perkara (Kisworo 2018).

\section{METODE PENELITIAN}

Penelitian ini merupakan penelitian hukum empiris (Soekanto 2015) dengan menggunakan pendekatan kuantitatif dan kualitatif (mixed approach). Data dikumpulkan dengan cara survei di mana sampel ditentukan secara non-probabilistik dengan cara aksidental, purposif dan bola salju (snow ball) dengan pertimbangan kemudahan dan luasnya subyek penelitian. Kriteria responden yaitu mereka yang dianggap layak oleh peneliti untuk menjadi ahli dalam perkara perdata lingkungan hidup di pengadilan yang berprofesi sebagai dosen, peneliti atau profesional di bidang lingkungan hidup. Data dikumpulkan dengan menggunakan kuesioner yang disusun oleh peneliti dan diisi oleh responden secara online (self-administered questionnaire). Jumlah sampel ditentukan berdasarkan kriteria variasi data penelitian (Aslichati, Prasetyo, dan Irawan 2017). Survei dilakukan dari tanggal 24 Februari 2020 hingga - 15 Maret 2020.

Informasi berdasarkan hasil survei dianalisa secara kuantitatif dengan metode statistik dengan bantuan software survei online Lime Survey yang bersifat open source dan secara kualitatif dengan menggunakan metode analisis isi (content analysis) dengan ditalikan pada teori dan hukum acara dalam konteks penyelesaian sengketa perdata lingkungan hidup di pengadilan dan data disajikan secara deskriptif. 
Vol. 2 No. 2 Juli 2020

\section{HASIL DAN PEMBAHASAN}

\subsection{Profil Responden}

Responden penelitian ini berjumlah 57 orang dengan keahlian yang beragam di bidang lingkungan hidup seperti hukum lingkungan, ilmu hukum, teknik lingkungan, lingkungan hidup secara umum, pengolahan air limbah, teknologi pengelolaan lingkungan, pengelolaan kualitas udara dan pengendalian pencemaran udara, proteksi lingkungan pertanian dan pengembangan masyarakat, sumber daya air, pengelolaan lingkungan hidup dan perubahan iklim, pengelolaan kualitas air, bioelectrochemistry dan pengolahan lumpur domestik dan industri, environmental remediation, sampling udara dan analisa sampel, pengelolaan sampah perkotaan, meteorology, konservasi landscape, pendidikan lingkungan hidup, manajemen lingkungan dan bencana geologi, akses informasi, partisipasi, desentralisasi, lingkungan pertambangan, perubahan iklim, hidrodinamika laut, serta geo-ekologi.

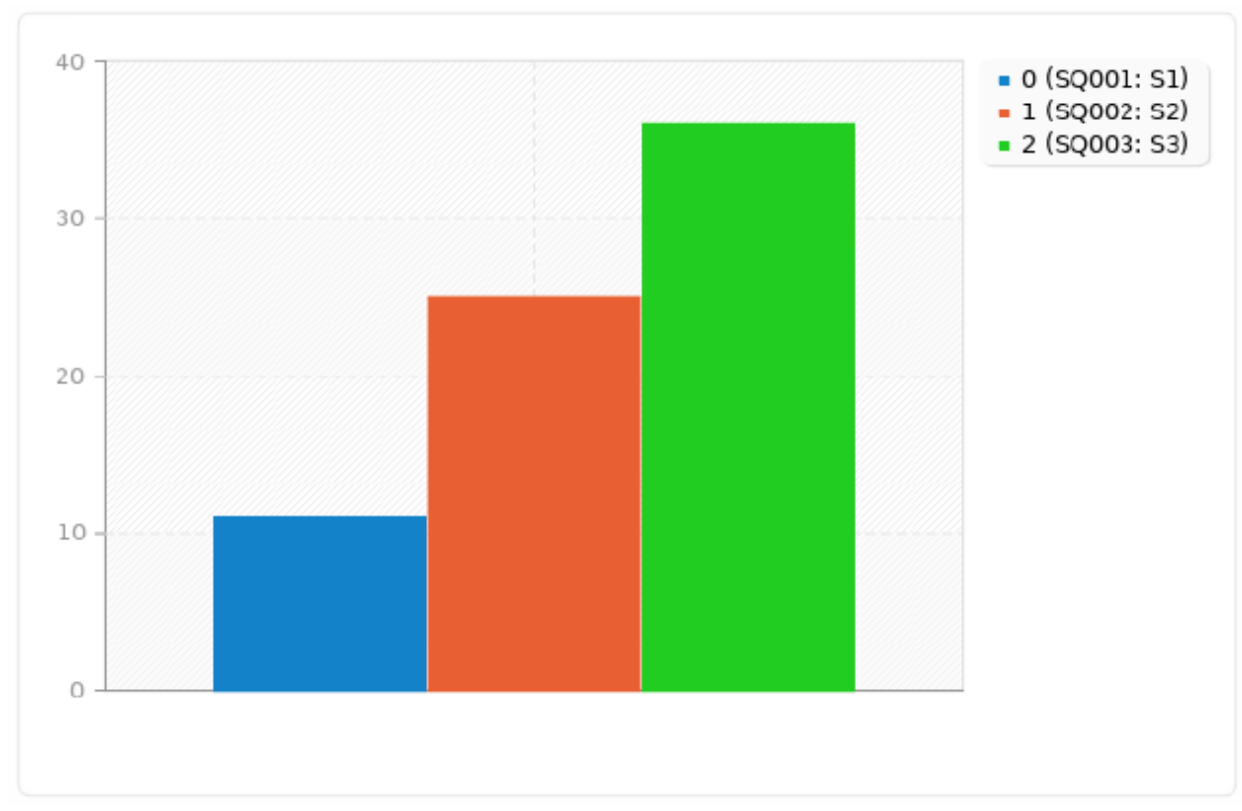

Grafik 1 Pendidikan Terakhir Responden

Pendidikan terkait keahlian responden seperti ditunjukan pada grafik 1 adalah Sarjana (S1) sebanyak 11 orang atau 19,30\%, Magister (S2) sebanyak 25 orang atau $43.86 \%$ dan 
Fakultas Hukum Universitas Komputer Indonesia

Vol. 2 No. 2 Juli 2020

Doktor (S3) sebanyak 36 orang atau 63,16\%. Bidang ilmu dalam pendidikan terkait keahlian meliputi ilmu lingkungan, teknik lingkungan, water resources, pengendalian pencemaran di industri, ecological engineering, lingkungan hidup, environmental management and technology, pure and applied biology, kimia, pertanian, klimatologi, kebijakan dan hukum lingkungan, environmental engineering and management, hukum internasional, ilmu hukum, teknologi pertanian, sistem pengelolaan lingkungan regional, serta rekayasa pertambangan.

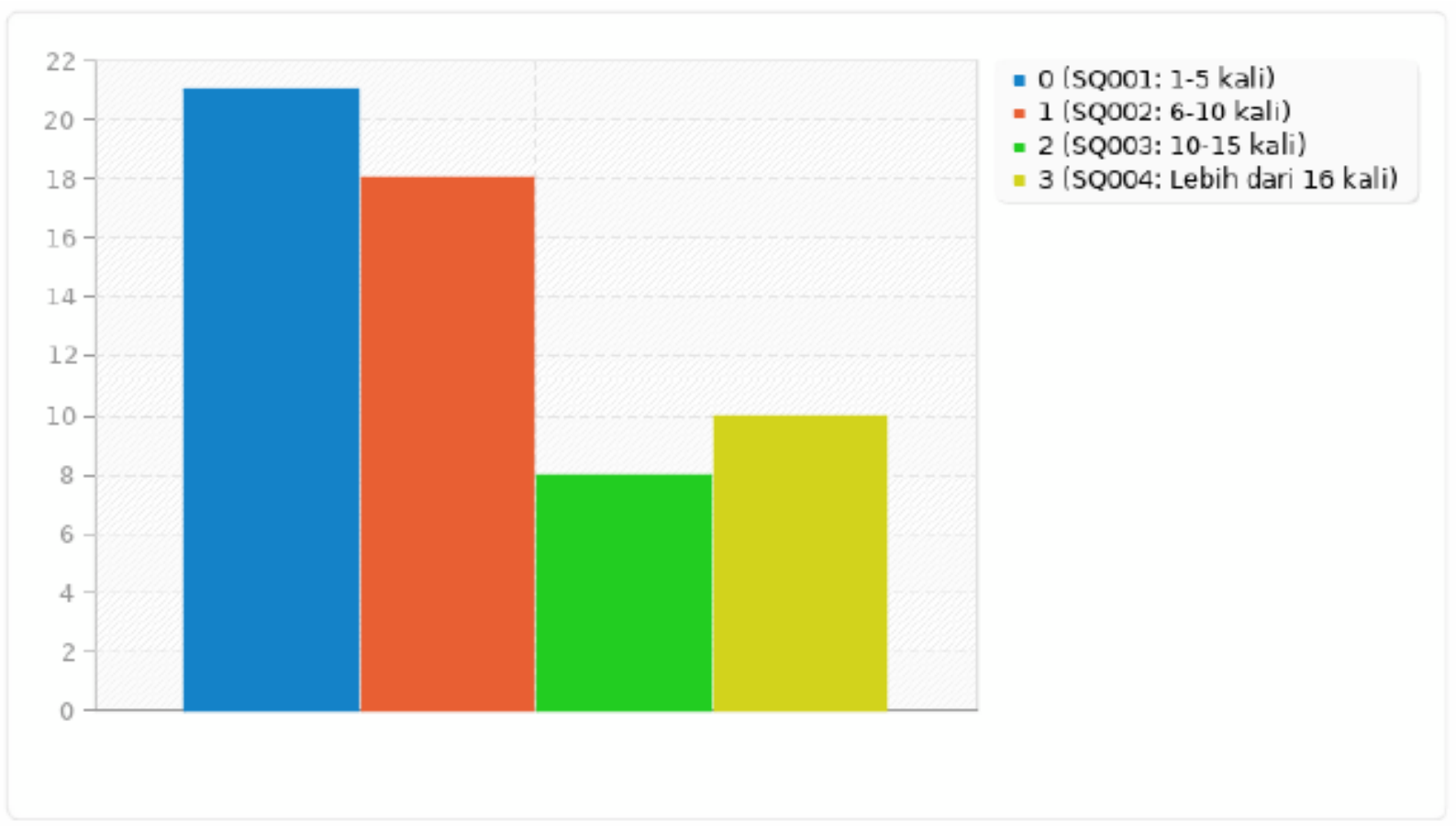

Grafik 2 Pelatihan yang Pernah diikuti Responden

Selain pendidikan formal, seperti ditunjukan pada Grafik 2, responden juga sudah pernah mendapatkan pelatihan terkait keahliannya sebanyak 1-5 kali (36, 84\%), 6-10 kali (31,58\%), 10-15 kali (14,04\%) dan lebih dari 16 kali (17,54\%). Seperti dijelaskan sebelumnya seorang ahli mendapatkan pengetahuan khusus selain karena pengalaman juga karena pelatihan yang diikutinya. 
Vol. 2 No. 2 Juli 2020

Sedangkan pengalaman responden seperti ditunjukan pada Grafik 3 di bidang keahliannya antara 1-5 tahun (1,75\%), 6-10 tahun (12,28\%), 11-15 tahun (26,32\%), 16-20 tahun $(28,07 \%)$ dan lebih dari 20 tahun $(31,58 \%)$.

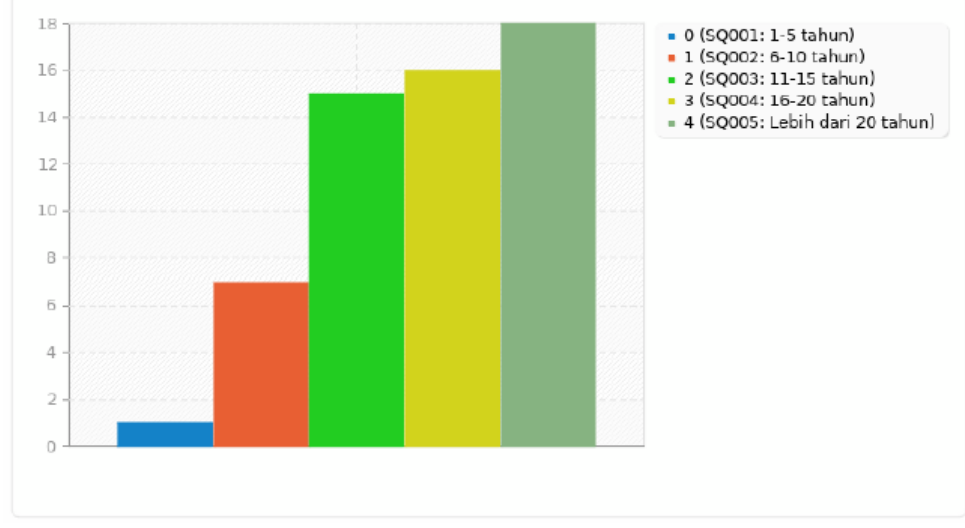

\section{Grafik 3 Pengalaman Responden di Bidang Keahliannya}

Sebanyak 66,67\% responden seperti ditunjukan pada Grafik 4 menyatakan pernah melakukan publikasi ilmiah dalam jurnal nasional, 64,91\% publikasi dalam jurnal internasional, $40.53 \%$ publikasi bab dalam buku, 22,81\% publikasi dalam bentuk buku, $56,14 \%$ dalam prosiding konferensi ilmiah nasional dan 64,91\% dalam prosiding konferensi ilmiah internasional. Sedangkan 14,04\% menyatakan karyanya dalam bentuk konten website, hak kekayaan intelektual seperti paten, perancangan peraturan perundang-undangan (legislative drafting), dokumen perencanaan, laporan studi dan ada juga yang tidak pernah melakukan publikasi sama sekali.

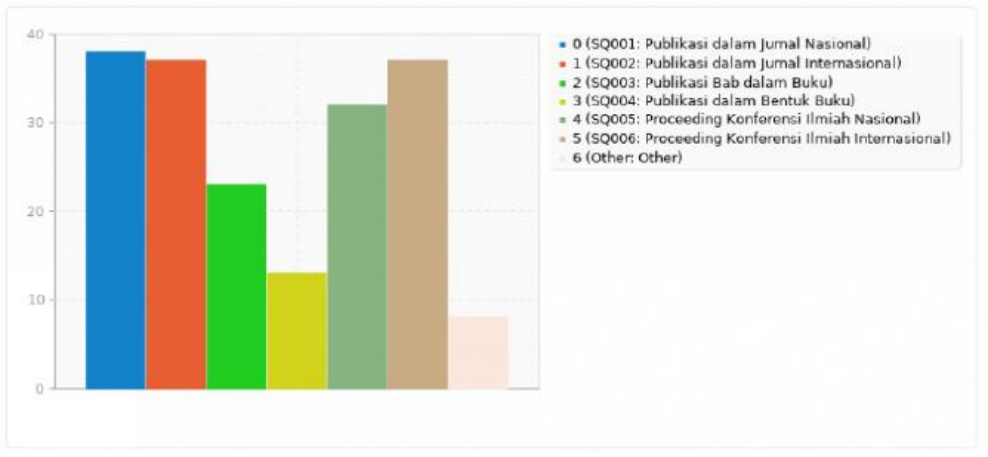

Grafik 4 Publikasi yang dilakukan Responden 
Vol. 2 No. 2 Juli 2020

Seperti ditunjukan pada Grafik 6, sebanyak 66,67\% responden bekerja sebagai dosen, $24,56 \%$ sebagai peneliti dan $12,28 \%$ sebagai profesional serta $7,02 \%$ pekerjaan lainnya. Responden bekerja di lembaga pendidikan negeri dan swasta, lembaga penelitian pemerintah, pegawai negeri sipil di instansi lingkungan hidup pusat dan daerah, profesional di institusi swasta serta lembaga swadaya masyarakat. Menurut Koesnadi Hardjasoemantri karena peran penting saksi ahli dalam perkara lingkungan, saksi ahli ini dapat diminta kepada Pusat Studi Lingkungan (PSL) yang ada di perguruan tinggi. Kerjasama yang erat menurutnya hendaknya dibina oleh pengadilan dan pusat studi lingkungan (Hardjasoemantri 2006).

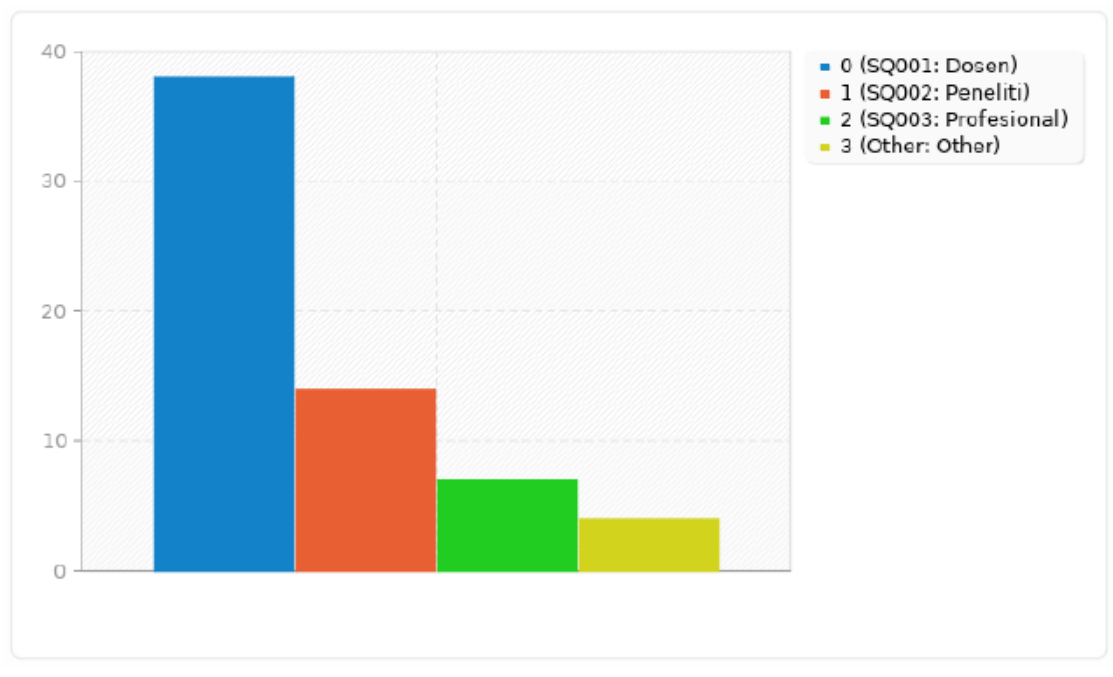

Grafik 5 Pekerjaan Responden

Menurut Undang-Undang Nomor 14 tahun 2005 Tentang Guru dan Dosen, dosen adalah pendidik profesional dan ilmuwan dengan tugas utama mentransformasikan, mengembangkan, dan menyebarluaskan ilmu pengetahuan, teknologi, dan seni melalui pendidikan, penelitian, dan pengabdian kepada masyarakat (Republik Indonesia 2005). Menurut Peraturan Kepala Lembaga Ilmu Pengetahuan Indonesia Nomor 08/E/2013 Tentang Pedoman Klirens Etik Penelitian dan Publikasi Ilmiah, peneliti adalah seseorang yang mempunyai tanggung jawab dalam penelitian ilmu pengetahuan sesuai dengan bidang kepakaran dan kompetensi yang diakui oleh peraturan yang berlaku serta dibina oleh lembaga pembina peneliti di Indonesia (LIPI 2013). Undang-Undang Nomor 11 
Vol. 2 No. 2 Juli 2020

Tahun 2019 Tentang Sistem Nasional Ilmu Pengetahuan dan Teknologi penelitian adalah kegiatan yang dilakukan menurut metodologi ilmiah untuk memperoleh data dan informasi yang berkaitan dengan pemahaman tentang fenomena alam dan/atau sosial, pembuktian kebenaran atau ketidakbenaran suatu asumsi dan/atau hipotesis, dan penarikan kesimpulan ilmiah (Republik Indonesia 2019). Selain ilmuwan seperti dosen dan peneliti, profesional di bidang lingkungan hidup juga dimungkinkan menjadi ahli di pengadilan sesuai dengan kebutuhan dan karakteristik kasusnya. Menuru Jassanof, Seorang ahli dapat berupa seorang praktisi (expert practioner), profesional (expertprofessional) atau ilmuwan (expert scientist) (Jasanoff 2008).

\subsection{Menjadi Ahli di Pengadilan}

Sebanyak 29.82\% responden (17 orang) sebagaimana ditunjukan pada Grafik 6 menyatakan pernah menjadi ahli di pengadilan, dan sisanya sebanyak $70.18 \%$ (40 orang) belum pernah.

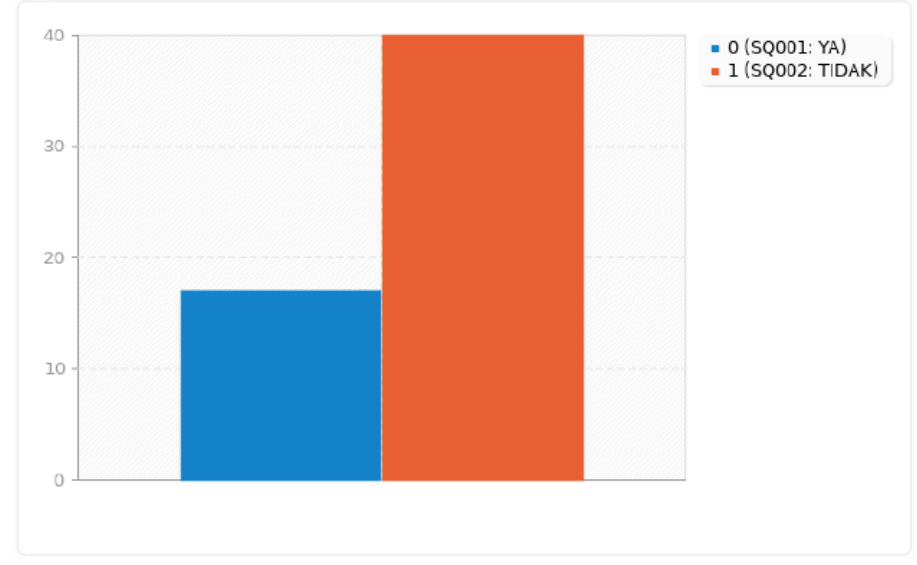

\section{Grafik 6 Pengalaman Menjadi Ahli di Pengadilan}

Yang pernah memberikan keterangan ahli (menjadi saksi ahli) di pengadilan sebanyak 14 orang $(24,56 \%)$ memberikannya antara $1-5$ kali, sebanyak 2 orang (3,51\%) antara 6-10 kali dan 1 orang (1.75\%) pernah memberikannya lebih dari 20 kali.

Seperti ditunjukan pada Grafik 8, secara keseluruhan, 31 orang $(54,39 \%)$ menyatakan bersedia untuk menjadi ahli dalam perkara perdata lingkungan hidup di pengadilan sedangkan 26 orang $(45,61 \%)$ tidak bersedia. 
Vol. 2 No. 2 Juli 2020

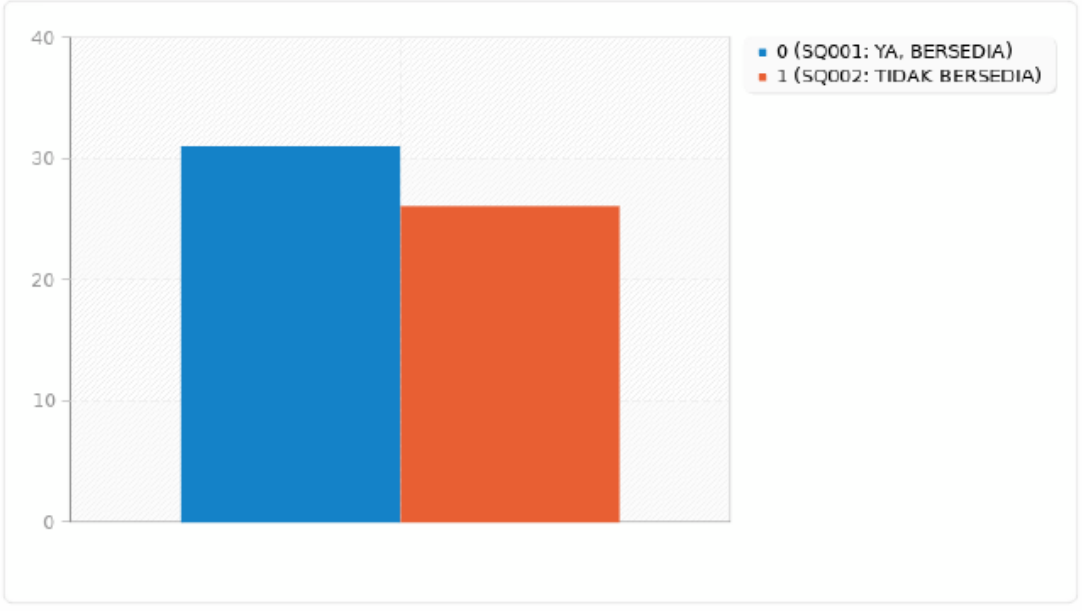

\section{Grafik 7 Kesediaan Memberikan Keterangan Ahli di Pengadilan}

Responden yang tidak bersedia memberikan keterangan ahli di pengadilan menyatakan kurang nyaman dengan suasana pengadilan sebanyak 8 orang $(14,04 \%)$, khawatir tidak dapat memberikan keterangan yang objektif sebanyak 6 orang (10,54\%), tidak ingin terlibat dalam konflik sebanyak 10 orang $(17,54 \%)$, belum tahu caranya atau belum pernah sebanyak 13 orang $(22,81 \%)$ serta kendala waktu sebanyak 12 orang (21.05\%) serta alasan lainnya 1 orang $(1,75 \%)$. Keterangan tambahan yang diberikan oleh responden adalah seringkali saksi ahli seperti menjadi terdakwa, mendapatkan pertanyaan-pertanyaan menyudutkan dan meragukan kemampuan, khawatir informasi hanya berasal dari para pihak yang bersengketa saja, adanya konflik yang sebenarnya biasanya di luar hal yang dibicarakan dalam konteks peradilan perkara lingkungan, belum pernah melihat suasana dalam pengadilan, khawatir tidak menguasai materi serta terikat pekerjaan lembaga. Ada juga yang menyatakan bentuk penyampaian keterangan ahli seharusnya presentasi dan diskusi, bukan menjawab pertanyaan yang ditanyakan hakim.

Responden yang bersedia memberikan keterangan ahli di pengadilan menyatakan sebagai tugas dan pengabdian pada masyarakat sebanyak 23 orang (40,35\%), membantu pengadilan agar dapat membuat keputusan yang baik sebanyak 28 orang $(49,12 \%)$ serta membantu para pihak yang bersengketa yang meminta bantuan sebanyak 6 orang $(21,05 \%)$. Alasan yang dikemukakan adalah sebagai warga negara adalah tugas agar ilmu dan pengetahuan yang dimiliki dapat dibagi pada masyarakat, masyarakat memerlukan 
Vol. 2 No. 2 Juli 2020

pendampingan dalam kasus lingkungan hidup, membantu menyelesaikan persoalan pencemaran dan perusakan lingkungan, serta sebagai salah satu tugas pokok dan fungsi dari seorang dosen berkewajiban menyebarluaskan ilmu pengetahuan, teknologi dan seni melalui fungsi pengabdian pada masyarakat.

Selain itu juga ada yang menyatakan walaupun agak menakutkan, tapi harus belajar melihat persoalan dari kacamata yang berbeda-beda dan mungkin jadi kebutuhan pengadilan, karena beberapa kali diminta untuk menjadi saksi ahli dalam penyelesaian sengketa lingkungan hidup di luar pengadilan oleh instansi lingkungan hidup, memberikan pandangan mengenai tema lingkungan pada perkara atau sengketa lingkungan sesuai dengan bidang keahlian, tanggung jawab memberikan kebenaran dari sudut pandang keilmuan yang dimiliki serta memberikan masukan dari sisi keilmuan. Selain itu juga ada yang menyatakan seorang dosen harus bisa bertindak sebagai academic leader di mana bisa memberikan pencerdasan kepada masyarakat dalam hal ini adalah pengadilan sehingga hakim dapat membuat keputusan terbaik. Pernyataan lain adalah sebagai bentuk peran serta untuk penyelesaian masalah atau sengketa berdasarkan keahlian di bidangnya serta dosen harus bisa bertindak bijaksana dalam memberikan keterangan di pengadilan.

Menjadi ahli di pengadilan dalam proses hukum yang bersifat contentiosa memang tidak selalu dapat dipahami sebagai tugas ilmuwan untuk melakukan pengabdian pada masyarakat. Pengajuan ahli oleh salah satu pihak dapat menimbulkan persepsi yang berbeda dan bahkan mungkin berujung pada gugatan hukum. Oleh karena itu tidak mengherankan apabila ada yang mengatakan menjadi ahli yang memperjuangkan kepentingan lingkungan hidup menjadi kebanggaan dan pengabdian pada bangsa dan negara dan meskipun banyak godaan namun harus mempertimbangkan sesuai dengan keilmuan dan keyakinan. Selain itu, menjadi ahli di pengadilan mungkin juga mempertimbangkan harapan dan menjadi ekspresi idealisme seorang ahli untuk memperjuangkan lingkungan yang baik dan sehat di samping harus mempunyai kemampuan dan pemahaman keilmuwan yang kuat serta kemampuan menjelaskan faktafakta hukum yang ada dan memiliki keberanian menghadapi berbagai ancaman maupun godaan dari pihak berperkara. Laporan ilmiah yang disusun ahli seharusnya mudah 
Vol. 2 No. 2 Juli 2020

dipahami oleh hakim karena pembuktian yang ahli sampaikan bertujuan membantu hakim memahami kasus dan peristiwa hukum dengan jelas (Virna P Setyorini 2018).

\subsection{Pandangan Terhadap Pihak yang Meminta Bantuan Ahli}

Terhadap pertanyaan mengenai pihak yang lebih tepat untuk meminta bantuan kepada ahli untuk memberikan keterangan di pengadilan, responden yang memilih hakim atau pengadilan sebanyak 32 orang atau $56,14 \%$, para pihak yang bersengketa masing-masing sebanyak 23 orang atau 40,35\%, persetujuan bersama para pihak yang bersengketa sebanyak 14 orang atau $24,58 \%$ serta hakim atau pengadilan dengan persetujuan bersama para pihak yang bersengketa sebanyak 29 orang atau 50,88\% serta alternatif lainnya 2 orang atau 3,51\%. Responden diperbolehkan untuk memberikan jawaban lebih dari satu. Secara grafis jawaban responden tersebut dapat digambarkan pada grafik 9 berikut ini.

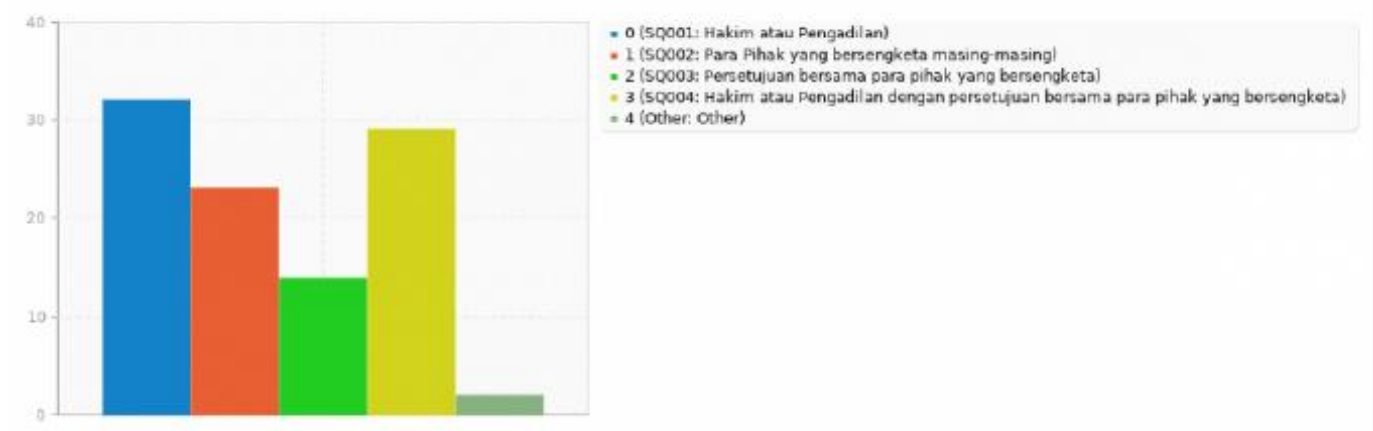

Grafik 8 Pandangan Tentang Pihak yang Lebih Tepat Meminta Bantuan Ahli di Pengadilan

Terhadap pertanyaan ini, responden ada yang memberikan respon tambahan berupa pendapat bahwa hakim adalah pihak yang paling tepat untuk menentukan meminta bantuan kepada ahli untuk memberikan keterangan di pengadilan dan persetujuan dari para pihak yang bersengketa hanya dijadikan second opinion sebagai bahan pertimbangan pengadilan dalam memutuskan saksi ahli. Pendapat ini juga kemungkinan terkait dengan pendapat pengadilan sebagai institusi yang harus bersikap adil dan untuk menghindari subyektifitas ahli sehingga ahli lebih netral dan tidak berpihak serta menghindari conflict of interest dan untuk memastikan independensi dan objektivitas ahli. Ada juga yang 
Vol. 2 No. 2 Juli 2020

melihat hal ini sebagai upaya agar tidak ada kesan pemihakan dan sebagai penguatan terhadap hakim dalam perkara lingkungan.

Ada yang mengemukakan pentingnya persetujuan para pihak adalah agar dicapai keterbukaan terhadap kemampuan ahli yang disetujui para pihak sehingga diharapkan akan menghasilkan kesepakatan yang dapat diterima semua pihak. Namun demikian, hak para pihak untuk meminta bantuan ahli juga menjadi pilihan, hal ini kemungkinan terkait dengan kondisi kasus lingkungan hidup di mana para pihak mungkin memerlukan bantuan ahli sebelum perkara masuk ke pengadilan.

\section{SIMPULAN}

Tidak semua ahli yang layak menjadi ahli sesuai bidang keahliannya bersedia untuk menjadi ahli dalam perkara perdata lingkungan hidup di pengadilan dengan alasan karena kurang nyaman dengan suasana pengadilan, khawatir tidak dapat memberikan keterangan yang objektif, tidak ingin terlibat dalam konflik, belum tahu caranya atau belum pernah serta kendala waktu. Namun demikian, tidak sedikit yang bersedia untuk menjadi ahli sesuai bidang keahliannya dalam perkara perdata lingkungan hidup di pengadilan dengan alasan sebagai bentuk tugas dan pengabdian pada masyarakat, membantu pengadilan agar dapat membuat keputusan yang baik serta membantu para pihak yang bersengketa yang meminta bantuan dalam penyelesaian sengketa di pengadilan. Bantuan ilmu pengetahuan dalam bentuk keterangan ahli lebih cenderung diminati agar yang meminta bantuan adalah pengadilan atau hakim termasuk dengan kesepakatan para pihak agar ahli lebih bisa bersikap objektif dan netral dalam memberikan pendapat sesuai keahliannya. Ahli yang ditunjuk pengadilan juga mungkin bisa mengatasi kendala ketidakseimbangan akses terhadap ahli diantara para pihak. Meskipun demikian, hal tersebut tidak menutup kemungkinan para pihak untuk meminta bantuan ahli sesuai dengan kebutuhan kondisi kasus lingkungan hidup.

Untuk memastikan objektifitas dan profesionalitas ahli dalam memberikan keterangan sebaik-baiknya sesuai pengetahuannya selain sumpah ahli di pengadilan, perlu juga dikaji masalah kode etik ahli serta pengembangan suatu register ahli yang dibuat oleh pengadilan atau organisasi lainnya yang memiliki perhatian pada akses terhadap ahli oleh 
Vol. 2 No. 2 Juli 2020

pengadilan dan para pihak yang terlibat dalam penyelesaian sengketa lingkungan di pengadilan secara independen.

\section{DAFTAR PUSTAKA}

Aslichati, Lilik, H.I. Bambang Prasetyo, dan Prasetya Irawan. 2017. Metode Penelitian Sosial. Tangerang Selatan: Universitas Terbuka.

Echols, John M., dan Hasan Shadily. 1992. Kamus Indonesia-Inggris. Jakarta: Gramedia Pustaka Utama.

Fakhriah, Efa Laela. 2013. "Small Claims Court in Environmental Disputes Resolution to Support the Realization of SustainableDevelopment." Sociology Study 3 (8): 588595.

- 2015. Perbandingan HIR dan RBG Sebagai Hukum Acara Perdata Positif di Indonesia. Bandung: Keni Media.

—. 2017. Bukti Elektronik Dalam Sistem Pembuktian Perdata. Bandung: Refika Aditama.

Hardjasoemantri, Koesnadi. 2006. Ekologi, Manusia dan Kebudayaan. Yogyakarta: Lapera Pustaka Utama.

Jasanoff, Sheila. 2005. "Science in court.” Nature, 3 Maret 2005.

—. 2008. "Representation and Re-Presentation in Litigation Science." Environmental Health Perspectives 116 (1): 123-29. https://doi.org/10.1289/ehp.9976.

Kisworo, Windu. 2018. "Aplikasi Prinsip-Prinsip Terkait Bukti Ilmiah (Scientific Evidence) di Amerika Serikat Dalam Pembuktian Perkara Perdata Lingkungan di Indonesia." Jurnal Hukum Lingkungan Indonesia 5 (1): 24-59.

LIPI. 2013. Peraturan Kepala Lembaga Ilmu Pengetahuan Indonesia Nomor 08/E/2013 Tentang Pedoman Klirens Etik Penelitian dan Publikasi Ilmiah.

Mahkamah Agung. 2013. Keputusan Ketua Mahkamah Agung Republik Indonesia Nomor: 36/KMA/SK/II/2013 Tentang Pemberlakuan Pedoman Penanganan Perkara Lingkungan Hidup.

Mas Achmad Santosa, Takdir Rahmadi, Sulaiman N. Sembiring, dan Rosa Vivien Ratnawati. 1997. Penerapan Asas Tanggung Jawab Mutlak (Strict Liability) di Bidang Lingkungan Hidup. Jakarta: Indonesian Center for Environmental Law.

Mish, Frederic C., ed. 2004. The Merriam Webster Dictionary. Massachusetts: MerriamWebster Incorporated.

Nicholson, David. 2009. Environmental Dispute Resolution in Indonesia. Leiden: KITLV Press. 
Vol. 2 No. 2 Juli 2020

Ozawa, Connie P. 1996. "Science in Environmental Conflicts." Sociological Pespectives 39 (2): 219-30.

Paulus Effendi Lotulung. 1993. Penegakan Hukum Lingkungan oleh Hakim Perdata. Bandung: PT. Citra Aditya Bakti.

Pusat Bahasa Departemen Pendidikan Nasional. 2015. Kamus Besar Bahasa Indonesia. Edisi Keempat. Jakarta: PT Gramedia Pustaka Utama.

Republik Indonesia. 2005. Undang-Undang Nomor 14 tahun 2005 Tentang Guru dan Dosen.

2019. Undang-Undang Nomor 11 Tahun 2019 Tentang Sistem Nasional Ilmu Pengetahuan dan Teknologi.

Sholihah, Arni Rahmawati Fahmi. 2011. "Peran Saksi Ahli Dan Laboratorium Dalam Penegakan Hukum Lingkungan." 12 Desember 2011. https://blogs.itb.ac.id/sholihah/2011/12/12/peran-saksi-ahli-dan-laboratoriumdalam-penegakan-hukum-lingkungan/.

Soekanto, Soerjono. 2015. Pengantar Penelitian Hukum. Jakarta: Penerbit Universitas Indonesia.

Takdir Rahmadi. 2012. Hukum Lingkungan di Indonesia. Jakarta: Rajawali Pers.

Virna P Setyorini. 2018. "KLHK kumpulkan ahli perkuat penegakan hukum lingkungan." ANTARA News, Oktober 2018. https://www.antaranews.com/berita/762545/klhkkumpulkan-ahli-perkuat-penegakan-hukum-lingkungan. 